\title{
Performance of Tomato (Solanum lycopersicum L.) in Acid Soil under Integrated Nutrient Management with Biochar as a Component
}

\author{
Oguboyana Srikanth Yadav and Sanjay Swami*
}

School of Natural Resource Management, College of Post Graduate Studies in Agricultural Sciences, Central Agricultural University, Umiam-793103, Meghalaya, India

*Corresponding author

\section{Keywords}

Biochar, INM,

Acidic soils, North eastern hill region, Tomato performance

\section{Article Info}

Accepted:

10 April 2019

Available Online:

10 May 2019

\section{A B S T R A C T}

Majority of the soils in the North Eastern Hill (NEH) region of India are acid in reaction causing low crop yields. The region produces huge quantity of crop residue/weed biomass which can be converted into biochar for managing soil acidity. To evaluate the performance of tomato (cv. Megha tomato-2) in acid soil of Meghalaya under integrated nutrient management having biochar as a component, an experiment was conducted during rabi season of 2017-18 at Research Farm of School of Natural Resource Management, CPGSAS, Umiam, Meghalaya and the following sixteen treatments were tested under RBD with three replications: $\mathrm{T}_{1}-$ Control, $\mathrm{T}_{2}-\mathrm{B} @ 2 \mathrm{t} / \mathrm{ha}, \mathrm{T}_{3}-\mathrm{B} @ 3 \mathrm{t} / \mathrm{ha}, \mathrm{T}_{4}-\mathrm{B} @ 4$ $\mathrm{t} / \mathrm{ha}, \mathrm{T}_{5}-75 \% \mathrm{RDF}+\mathrm{B} @ 2 \mathrm{t} / \mathrm{ha}, \mathrm{T}_{6}-75 \% \mathrm{RDF}+\mathrm{B} @ 3 \mathrm{t} / \mathrm{ha}, \mathrm{T}_{7}-75 \% \mathrm{RDF}+\mathrm{B} @ 4$ t/ha, $\mathrm{T}_{8}-75 \% \mathrm{RDF}+\mathrm{B} @ 2 \mathrm{t} / \mathrm{ha}+\mathrm{VC} @ 2.5 \mathrm{t} / \mathrm{ha}, \mathrm{T}_{9}-75 \% \mathrm{RDF}+\mathrm{B} @ 3 \mathrm{t} / \mathrm{ha}+\mathrm{VC} @$ $2.5 \mathrm{t} / \mathrm{ha}, \mathrm{T}_{10}-75 \% \mathrm{RDF}+\mathrm{B} @ 4 \mathrm{t} / \mathrm{ha}+\mathrm{VC} @ 2.5 \mathrm{t} / \mathrm{ha}, \mathrm{T}_{11}-100 \% \mathrm{RDF}+\mathrm{B} @ 2 \mathrm{t} / \mathrm{ha}, \mathrm{T}_{12}-$ $100 \% \mathrm{RDF}+\mathrm{B} @ 3 \mathrm{t} / \mathrm{ha}, \mathrm{T}_{13}-100 \% \mathrm{RDF}+\mathrm{B} @ 4 \mathrm{t} / \mathrm{ha}, \mathrm{T}_{14}-100 \% \mathrm{RDF}+\mathrm{B} @ 2 \mathrm{t} / \mathrm{ha}+$ VC@ 2.5 t/ha, $\mathrm{T}_{15}-100 \% \mathrm{RDF}+\mathrm{B} @ 3 \mathrm{t} / \mathrm{ha}+\mathrm{VC} @ 2.5 \mathrm{t} / \mathrm{ha}, \mathrm{T}_{16}-100 \% \mathrm{RDF}+\mathrm{B} @ 4$ $\mathrm{t} / \mathrm{ha}+\mathrm{VC} @ 2.5 \mathrm{t} / \mathrm{ha}$. The experimental results revealed that the highest plant height $(\mathrm{cm})$ and number of fruits/plant was recorded in the treatment $\mathrm{T}_{16}-100 \% \mathrm{RDF}+\mathrm{B} @ 4 \mathrm{t} / \mathrm{ha}+$ VC @ 2.5 t/ha with 150 and 127 percent increase over control, respectively. Average fruit weight $(66.12 \mathrm{~g})$, fruit yield ( $38.85 \mathrm{t} / \mathrm{ha})$, fruit dry matter $(5.22 \mathrm{t} / \mathrm{ha})$ and haulm dry matter (3.19 t/ha) was recorded highest in the treatment $\mathrm{T}_{16}-100 \% \mathrm{RDF}+\mathrm{B} @ 4 \mathrm{t} / \mathrm{ha}+\mathrm{VC} @$ $2.5 \mathrm{t} / \mathrm{ha}$ which were significantly higher over all other treatments indicating that the application of biochar@ @ t/ha in combination with vermicompost @ $2.5 \mathrm{t} / \mathrm{ha}$ and 100\% RDF was most effective in increasing tomato yield in acid soil than sole application of biochar or biochar in combination with recommended doses of chemical fertilizers.

\section{Introduction}

Soil is the basic foundation for sustainable crop production and the soil quality effects crop production. Out of 142 million ha of cultivable area in India, 49 million ha of area is acidic, of which 26 million ha of area having soil $\mathrm{pH}<5.5$ and the rest 23 million ha of area having soil $\mathrm{pH}$ range 5.6 to 6.5 . Approximately, 84 per cent of the soils in the North Eastern Hill (NEH) region of India are acidic in reaction, having low available 
phosphorus (P) and zinc whereas toxicity of iron and aluminium (Lyngdoh and SanjaySwami, 2018). In acid soils, $\mathrm{P}$ adsorption is generally attributed to hydrous oxides of iron and aluminium. There is great possibility that some natural phosphates of aluminium or iron (such as variscite and strengite) may formed in these soils making $\mathrm{P}$ the most limiting nutrient for crop production (Sanjay-Swami and Maurya, 2018; Sanjay-Swami et al., 2019). In Meghalaya, the acid soils are found under different acidic ranges like moderately acidic soils (1.19 million ha), and slightly acidic soils (1.05 million ha) (Maji et al., 2012). The soils of Meghalaya are high in organic carbon, which is a measure of supplying potential of soil nitrogen, deficient in available phosphorous, medium to low in available potassium, calcium, magnesium and toxic in $\mathrm{Al}$ and $\mathrm{Fe}$. To overcome the problem of soil acidity, farmers adopt variety of soil amendments like manures, lime and composts to make soil nutrients available to crops as well as to protect them from the toxic elements. Among soil amendments, liming is good practice to overcome the acidity problem; however, it may not be economical in the regions where it is expensive. Biochar is an alternative, good and cheap organic source to overcome the soil acidity problem (Chan et al., 2008, Yadav and Sanjay-Swami, 2018).

Biochar is a carbonaceous solid material obtained from thermally degrading biomass in the absence of oxygen or presence of little oxygen. It is commonly defined as charred organic matter, produced with the intention to apply in the soils to sequester carbon and improve soil physical and chemical properties (Lehmann and Joseph, 2009). It is produced by processes called pyrolysis, the direct thermal decomposition of biomass in the absence of oxygen which produces a mixture of solids (biochar), gas (syngas) and liquid (bio oil). Yield and quality of biochar depends on maintaining of specific temperature (Demirbas, 2004; Sanjay-Swami et. al., 2018). Temperature of $400-500^{\circ} \mathrm{C}$ produces more quantity of biochar, while temperatures above $700^{\circ} \mathrm{C}$ favour the yield of liquid and gas fuel components. The major resource required for the production of the biochar is organic residue. The NEH region produces huge quantity of crop residue/weed biomass which can be converted into biochar for managing soil acidity (Yadav and SanjaySwami, 2018). Soil health management in the fragile ecosystems of the NEH region should be based on recycling of available plant residues, agro-forestry, and integrated nutrient management (Sanjay-Swami, 2019). Biochar has numerous beneficial effects to soils used for agricultural purposes. The application of charcoal to the soil for improving its physical condition is an old practice (Renner, 2007). There are reports in the literature that biochar in combination with inorganic fertilizers had shown significant increase in yield of cowpea, maize and peanut (Yamato et al., 2006), paddy (Zhang et al., 2012), spring barley, winter wheat, carrots, spinach, oilseed rape, peas and beetroot (Hammond et al., 2013). However, meager information is available on integrating biochar with organic manures and chemical fertilizers. Therefore, the present investigation was carried out to evaluate the performance of tomato (cv. Megha tomato-2) in acid soil of Meghalaya under integrated nutrient management having biochar as a major component.

\section{Materials and Methods}

A field experiment was conducted during rabi season of 2017-18 at Research Farm of School of Natural Resource Management, College of Post Graduate Studies in Agricultural Sciences (CPGSAS), Umiam, Ri-bhoi district, Meghalaya which is located at 91018 ' to 92018 ' E longitude and 25040' to $26020^{\prime} \mathrm{N}$ latitude with an altitude of $950 \mathrm{~m}$ 
above the mean sea level. The experimental area falls under subtropical humid climate with high rainfall and cold winter. Tomato cv. Megha tomato-2 was used as test crop with three doses of biochar (B) @ 2, 3 and 4 t/ha, vermicompost (VC) @ 2.5 t/ha and two graded recommended doses of NPK fertilizers (RDF) @ 75 and 100\%. The trial was replicated three times adopting Randomized Block Design (RBD) with 16 treatment combinations namely, $\mathrm{T}_{1}$ - Control, $\mathrm{T}_{2}$ - B @ 2 t/ha, T 3 - B@ 3 t/ha, T - B @ 4 t/ha, T 75\% RDF+B@2t/ha, $\mathrm{T}_{6}-75 \% \mathrm{RDF}+\mathrm{B}$ @ $3 \mathrm{t} / \mathrm{ha}, \mathrm{T}_{7}-75 \% \mathrm{RDF}+\mathrm{B} @ 4 \mathrm{t} / \mathrm{ha}, \mathrm{T}_{8}$ 75\% RDF + B @ 2 t/ha + VC @ 2.5 t/ha, T 9 75\% RDF+B@3t/ha+VC@2.5t/ha, T 10 75\% RDF+B@4t/ha + VC @ $2.5 \mathrm{t} / \mathrm{ha}, \mathrm{T}_{11}$ - 100\% RDF+B @ 2t/ha, T 12 - 100\% RDF + B@3t/ha, $\mathrm{T}_{13}-100 \% \mathrm{RDF}+\mathrm{B} @ 4 \mathrm{t} / \mathrm{ha}$, $\mathrm{T}_{14}-100 \% \mathrm{RDF}+\mathrm{B} @ 2 \mathrm{t} / \mathrm{ha}+\mathrm{VC} @ 2.5$ t/ha, T $15-100 \%$ RDF + B @ 3 t/ha+VC @ $2.5 \mathrm{t} / \mathrm{ha}, \mathrm{T}_{16}-100 \% \mathrm{RDF}+\mathrm{B} @ 4 \mathrm{t} / \mathrm{ha}+\mathrm{VC}$ @ $2.5 \mathrm{t} / \mathrm{ha}$. The experimental soil was acidic in reaction having $\mathrm{pH} 5.1$ and medium in available phosphorus $(18.70 \mathrm{~kg} / \mathrm{ha})$. The detailed analysis of experimental soil is presented in Table 1.

The biochar utilized in this study was prepared through pyrolysis by using waste from the plywood industry as a feedstock source at ICAR Research Complex for NEH Region, Umiam whereas vermicompost was procured from Rural Resource and Training Centre, Umran. The characteristics of biochar and vermicompost along with the method of analysis are provided in Table 2.

The biochar and vermicompost at required rate were applied 15 days before transplanting of tomato seedlings and mixed well in the surface soil. The growth and yield parameters of tomato were recorded at maturity. The data recorded for various parameters were analysed statistically by following procedure of Gomez and Gomez (1984).

\section{Results and Discussion}

\section{Plant height (cm)}

Plant height is the observable parameter which helps to assess the effectiveness of various treatments. The plant height of tomato recorded under different treatments is presented in Table 3. The highest plant height $(56.2 \mathrm{~cm})$ was recorded with the application of $100 \% \mathrm{RDF}+$ biochar @ $4 \mathrm{t} / \mathrm{ha}+$ vermicompost @ $2.5 \mathrm{t} / \mathrm{ha}\left(\mathrm{T}_{16}\right)$, whereas the lowest plant height $(37.4 \mathrm{~cm})$ was observed under control plots $\left(\mathrm{T}_{1}\right)$. The sole application of biochar@ 2 t/ha slightly increased plant height over control plots $\left(\mathrm{T}_{1}\right)$. Further, successive increase in biochar doses i.e. 3 and 4 t/ha also increased plant hight over each lower doses of biochar. Biochar has been reported to modify soil quality characteristics. As it was alkaline in nature $(\mathrm{pH}$ 8.6), probably the $\mathrm{pH}$ of acidic soil under study (5.1) improved, thereby increasing crop growth and yields. The similar findings were also reported by Novak et al., (2013).

The combined application of $75 \% \mathrm{RDF}$ and biochar markedly increased the plant height over sole application of biochar at respective graded doses, whereas the combination of $75 \% \mathrm{RDF}+$ biochar + vermicompost @ 2.5 t/ha significantly increased the plant height over sole application of biochar at respective graded doses. A close scrutiny of data also revealed that the combined application of $100 \%$ RDF and biochar significantly increased the plant height over sole application of biochar at respective graded doses, however, the addition of vermicompost @ 2.5 t/ha with $100 \%$ RDF and biochar further increased the plant height over $100 \%$ $\mathrm{RDF}$ and biochar at respective graded doses. The research findings with respect to plant height are also in concurrence with the findings of Mohideen (2018) who observed better growth of chilli with the application of 
Gliciridia biochar $+100 \%$ urea over sole applications. The probable reason for further improvement in plant height with the addition of vermicompost along with $100 \%$ RDF and biochar is the additional supply of plant nutrients as well as improvement in physical and biological properties of soil by vermicompost (Sanjay-Swami and Bazaya, 2010; Konyak and Sanjay-Swami, 2018; Gupta et al., 2019).

\section{Number of fruits/plant}

Number of fruits/plant was recorded least (7.40) in control plots which slightly increased with each successive higher doses of biochar (Table 3). The combined application of $100 \%$ RDF and biochar significantly increased the number of fruits/plant over sole application of biochar at respective graded doses and it was at par with the combined application of $75 \% \mathrm{RDF}+$ biochar + vermicompost @ 2.5 t/ha at respective graded doses of biochar. The number of fruits/plant further increased with the addition of vermicompost @ 2.5 t/ha with $100 \%$ RDF and biochar at respective doses of biochar and the maximum number of fruits/plant was recorded in the treatment receiving 100\% RDF + biochar@ @ t/ha + vermicompost @ $2.5 \mathrm{t} / \mathrm{ha}\left(\mathrm{T}_{16}\right)$.

The increased number of fruits/plants observed under study may be due to the fact that number of fruits are dependent on canopy size and vigour of plants which is observed higher under $\mathrm{T}_{16}$ with $100 \% \mathrm{RDF}+$ biochar @ $4 \mathrm{t} / \mathrm{ha}+$ vermicompost @ $2.5 \mathrm{t} / \mathrm{ha}$. These results corroborate the findings of Antonious (2018) who reported that addition of biochar $(1 \% \mathrm{w} / \mathrm{w})$ to sewage sludge (SS) and yard waste (YW) treatments significantly increased number of fruits/plant in tomato indicating a positive effect of biochar on the growth at University of Kentucky, Lexington, Kentucky.

\section{Average fruit weight (g)}

The sole application of biochar @ 2 t/ha markedly and significantly increased average fruit weight $(\mathrm{g})$ of tomato over control plots $\left(\mathrm{T}_{1}\right)$, however, further successive increase in biochar doses i.e. 3 and 4 t/ha slightly increased average fruit weight over each lower doses of biochar (Table 3). The combined application of $75 \% \mathrm{RDF}$ and biochar significantly increased the average fruit weight over sole application of biochar at respective graded doses. Similarly, the inclusion of vermicompost @ 2.5 t/ha with $75 \%$ RDF + biochar significantly increased the plant height over $75 \% \mathrm{RDF}$ and biochar at respective graded doses. However, nonsignificant increase in average fruit weight was observed with further increase in RDF to $100 \%$ in combination with biochar over $75 \%$ RDF and biochar at respective graded doses. The examination of data further revealed that the combined application of $75 \% \mathrm{RDF}+$ biochar + vermicompost @ 2.5 t/ha was superior over $100 \%$ RDF and biochar at respective graded doses with more average fruit weight. However, the addition of vermicompost@2.5 t/ha with 100\% RDF + biochar further increased the average fruit weight over $100 \%$ RDF and biochar at respective graded doses and the maximum average fruit weight $(66.12 \mathrm{~g})$ was observed with the application of $100 \% \mathrm{RDF}+$ biochar @ $4 \mathrm{t} / \mathrm{ha}+$ vermicompost @ $2.5 \mathrm{t} / \mathrm{ha}\left(\mathrm{T}_{16}\right)$.

The higher average fruit weight recorded with the application of biochar over control is possibly due to improvement in soil properties and increased nutrient availability (Lehmann et al., 2003; Oguntunde et al., 2004; Lehmann et al., 2006; Deluca et al., 2009). However, the addition of biochar with RDF significantly increased the nutrient availability due to increased nutrients supply maintained by chemical fertilizers. These results are in agreement with the findings of 
Mohideen (2018) who also reported improvement in average fruit weight of chilli with the application of Gliciridia biochar + $100 \%$ urea over sole applications. Further, inclusion of vermicompost @ 2.5 t/ha with $100 \%$ RDF + biochar further improved average fruit weight of tomato due to combined beneficial effect. The beneficial effect of vermicompost on average fruit weight might be due to additional supply of plant nutrients as well as improvement in physical and biological properties of soil (Sanjay-Swami and Bazaya, 2010; Konyak and Sanjay-Swami, 2018; Gupta et al., 2019). The highest average fruit weight $(66.12 \mathrm{~g})$ observed under $\mathrm{T}_{16}$ corroborates the findings of CRIDA (2016).

\section{Fresh fruit yield (t/ha)}

The fresh fruit yield of tomato under different treatment varied from 8.32 to $38.86 \mathrm{t} / \mathrm{ha}$ (Table 4). The data indicated that the sole application of biochar at different graded doses i.e. 2, 3 and 4 t/ha significantly increased the fruit yield over control plots $\left(\mathrm{T}_{1}\right)$ which recorded lowest fruit yield (8.32 t/ha). However, successive increase in biochar doses from lowest level of 2 t/ha to 3 and 4 t/ha slightly increased fruit yield over lower doses. The combined application of $75 \% \mathrm{RDF}$ and biochar significantly increased the fruit yield over sole application of biochar at respective graded doses as well as over control plots. Further, significant increase in fruit yield was observed with subsequent increase in RDF to $100 \%$ in combination with biochar over $75 \% \mathrm{RDF}$ and biochar at respective graded doses. Similarly, the inclusion of vermicompost @ 2.5 t/ha with $75 \%$ RDF + biochar significantly increased the fruit yield over $75 \%$ RDF and biochar at respective graded doses. The fruit yield obtained with 75\% RDF + biochar + vermicompost @ 2.5 t/ha was observed to be superior over $100 \% \mathrm{RDF}$ and biochar at respective graded doses. However, the addition of vermicompost @ 2.5 t/ha with $100 \% \mathrm{RDF}+$ biochar further increased the fruit yield over $100 \% \mathrm{RDF}$ and biochar at respective graded doses and the maximum fruit yield (38.86 t/ha) was recorded with the application of $100 \%$ RDF + biochar @ 4 t/ha + vermicompost @ 2.5 t/ha $\left(\mathrm{T}_{16}\right)$.

Application of biochar significantly increased fresh fruit yield of tomato over control. Lehmann et al., (2003) also observed the immediate beneficial effects of biochar addition to soil due to higher $\mathrm{P}$ availability, because it may contribute as a source of available and exchangeable $\mathrm{P}$, ameliorator of $\mathrm{P}$ complexing metals $\left(\mathrm{Ca}^{2+}, \mathrm{Al}^{3+}\right.$ and $\left.\mathrm{Fe}^{3+, 2+}\right)$, as a promoter of microbial activity and $\mathrm{P}$ mineralization (Deluca et al., 2009). The results obtained under present investigation also confirmed the findings of Oguntunde et al., (2004) who compared maize yields between disused charcoal production sites and adjacent fields, Kotokosu watershed, Ghana and observed 91 per cent higher grain yield and 44 per cent higher biomass yield on charcoal site than control. Lehmann et al., (2006) again advocated that biochar application boosts up the soil fertility and improves soil quality by raising soil $\mathrm{pH}$, increasing moisture holding capacity, attracting more beneficial fungi and microbes, improving cation exchange capacity and retaining nutrients in soil, thereby increasing crop yields.

The addition of biochar with RDF also significantly increased the nutrient availability due to increased nutrient supply through chemical fertilizers. Yamato et al., (2006) also reported that Acacia bark charcoal plus fertilizer increased maize and peanut yields in area of low soil fertility. Inclusion of vermicompost@ 2.5 t/ha with 100\% RDF + biochar further improved average fruit weight of tomato that might be due to combined 
beneficial effect biochar and vermicompost in maintaining additional supply of plant nutrients as well as improvement in physical and biological properties of soil (SanjaySwami and Bazaya, 2010; Konyak and Sanjay-Swami, 2018; Gupta et al., 2019). The maximum fruit yield $(38.86 \mathrm{t} / \mathrm{ha})$ recorded with the application of $100 \%$ RDF + biochar @ $4 \mathrm{t} / \mathrm{ha}+$ vermicompost @ $2.5 \mathrm{t} / \mathrm{ha}\left(\mathrm{T}_{16}\right)$ is in agreement with the findings of CRIDA (2016) wherein eight treatments viz. $\mathrm{T}_{1}$ Control, $\mathrm{T}_{2}-\mathrm{RDF}$ (120-60-60), $\mathrm{T}_{3}-$ Biochar (2 t/ha), $T_{4}-$ Biochar (4 t/ha), $T_{5}-\mathrm{RDF}+$ Biochar (2 t/ha), $\mathrm{T}_{6}-\mathrm{RDF}+\operatorname{Biochar}(4 \mathrm{t} / \mathrm{ha})$, $\mathrm{T}_{7}-\mathrm{RDF}+$ Biochar (2t/ha) $+\mathrm{FYM}(5 \mathrm{t} / \mathrm{ha})$, $\mathrm{T}_{8}-\mathrm{RDF}+$ Biochar (4 t/ha) + FYM (5 t/ha) were tested in a rainfed Alfisol (Typic Haplustalf) to evaluate maize (DHM 117) performance and observed maximum yield with RDF + Biochar (4 t/ha) + FYM (5 t/ha).

\section{Fruit and haulm dry matter (t/ha)}

The highest fruit and haulm dry matter yield of tomato was recorded as 5.22 and $3.19 \mathrm{t} / \mathrm{ha}$ with the application of $100 \%$ RDF + biochar @ $4 \mathrm{t} / \mathrm{ha}+$ vermicompost @ $2.5 \mathrm{t} / \mathrm{ha}\left(\mathrm{T}_{16}\right)$ which was approximately 6 and 7 fold more over control plots (Table 4). The fruit and haulm dry matter of tomato significantly increased with the sole application of biochar at different graded doses i.e. 2, 3 and 4 t/ha over control plots $\left(T_{1}\right)$ which recorded lowest fruit and haulm dry matter (0.86 and 0.46 t/ha).

Table.1 Physico-chemical properties of experimental soil along with methods followed for analysis

\begin{tabular}{|c|c|c|c|}
\hline Parameters & Value & Methods & References \\
\hline pH & 5.10 & Potentiometry & Jackson (1973) \\
\hline EC(dS/m) & 0.45 & Conductometry & Jackson (1973) \\
\hline Bulk density $\left(\mathrm{g} / \mathrm{cm}^{3}\right)$ & 1.43 & Clod method & Campbell and Henshall (2001) \\
\hline Available N (kg/ha) & 261.00 & $\begin{array}{l}\text { Alkaline potassium } \\
\text { permanganate method }\end{array}$ & Subbiah and Asija (1956) \\
\hline Available $\mathrm{P}_{2} \mathrm{O}_{5}(\mathrm{~kg} / \mathrm{ha})$ & 18.70 & Brays No. 1 & Jackson (1973) \\
\hline Available $\mathrm{K}_{2} \mathrm{O}$ (kg/ha)) & 235.15 & Flame photometer method & Jackson (1973) \\
\hline \multicolumn{4}{|c|}{ DTPA extractable micronutrients (ppm) } \\
\hline Iron & 6.18 & \multirow{4}{*}{$\begin{array}{l}\text { Atomic absorption } \\
\text { spectrophotometry }\end{array}$} & \multirow{4}{*}{ Lindsay and Norwell (1978) } \\
\hline Zinc & 36.48 & & \\
\hline Manganese & 48.43 & & \\
\hline Copper & 16.78 & & \\
\hline \multicolumn{4}{|c|}{ Soil acidity indices $(\mathbf{c m o l}(\mathbf{p}+) / \mathbf{k g})$} \\
\hline Exchangeable acidity & 3.02 & Titrimetric determination & Jackson (1973) \\
\hline $\begin{array}{l}\text { Exchangeable } \\
\text { aluminium }\end{array}$ & 2.25 & Titrimetric determination & Jackson (1973) \\
\hline Exchangeable Ca \& Mg & 1.33 & $\begin{array}{l}\text { Complexometric titration } \\
\text { method }\end{array}$ & Jackson (1973) \\
\hline $\begin{array}{l}\text { Cation exchange } \\
\text { capacity }\end{array}$ & 7.33 & $\begin{array}{l}\text { Ammonium acetate } \\
\text { saturation method }\end{array}$ & Jackson (1973) \\
\hline
\end{tabular}


Table. 2 Characteristics of biochar and vermicompost used in the study along with methods followed for analysis

\begin{tabular}{|c|c|c|c|c|}
\hline Parameters & Biochar & Vermicompost & Methods & References \\
\hline pH & 8.60 & 7.30 & Potentiometry & Jackson (1973) \\
\hline $\mathrm{EC}(\mathrm{dS} / \mathrm{m})$ & 1.77 & - & Conductometry & Jackson (1973) \\
\hline Nitrogen $(\%)$ & 0.61 & 2.11 & $\begin{array}{l}\text { Kjeldahl digestion and } \\
\text { distillation method }\end{array}$ & Jackson (1973) \\
\hline Phosphorus (\%) & 0.22 & 1.23 & Vanadomolybdate method & Jackson (1973) \\
\hline Potassium $(\%)$ & 1.01 & 1.53 & Flame photometer method & Jackson (1973) \\
\hline \multicolumn{5}{|c|}{ DTPA extractable micronutrients (ppm) } \\
\hline Iron & 0.06 & 250.20 & \multirow{4}{*}{$\begin{array}{l}\text { Atomic absorption } \\
\text { spectrophotometry }\end{array}$} & \multirow{4}{*}{ Lindsay and Norwell (1978) } \\
\hline Zinc & 1.72 & 1095.00 & & \\
\hline Manganese & 0.04 & 53.00 & & \\
\hline Copper & 0.12 & 248.60 & & \\
\hline
\end{tabular}

Table.3 Growth and yield attributing characters of tomato (Solanum lycopersicum L.) in acid soil under integrated nutrient management with biochar as a component

\begin{tabular}{|c|c|c|c|}
\hline Treatments & $\begin{array}{l}\text { Plant height } \\
\text { (cm) }\end{array}$ & $\begin{array}{l}\text { Number of } \\
\text { fruits/plant }\end{array}$ & $\begin{array}{l}\text { Average fruit } \\
\text { weight (g) }\end{array}$ \\
\hline $\mathbf{T}_{1}$ - Control & 37.4 & 7.40 & 17.94 \\
\hline $\mathbf{T}_{2}$-Biochar@2t/ha & 38.1 & 7.52 & 25.74 \\
\hline$T_{3}$-Biochar@3 t/ha & 39.0 & 7.68 & 30.72 \\
\hline$T_{4}$ - Biochar@ 4 t/ha & 39.5 & 7.92 & 33.73 \\
\hline $\mathrm{T}_{5}-75 \% \mathrm{RDF}+$ Biochar @ 2 t/ha & 44.4 & 8.40 & 35.14 \\
\hline $\mathrm{T}_{6}-75 \%$ RDF + Biochar @ $3 \mathrm{t} / \mathrm{ha}$ & 45.8 & 8.60 & 39.44 \\
\hline $\mathrm{T}_{7}-75 \% \mathrm{RDF}+$ Biochar @ $4 \mathrm{t} / \mathrm{ha}$ & 47.8 & 8.72 & 42.75 \\
\hline $\begin{array}{l}\mathrm{T}_{8}-75 \% \mathrm{RDF}+\text { Biochar @ } 2 \mathrm{t} / \mathrm{ha}+ \\
\text { Vermicompost @ } 2.5 \mathrm{t} / \mathrm{ha}\end{array}$ & 47.2 & 8.68 & 41.47 \\
\hline $\begin{array}{l}\text { T }_{9}-75 \% \text { RDF + Biochar @ } 3 \text { t/ha + } \\
\text { Vermicompost @ } 2.5 \text { t/ha }\end{array}$ & 53.6 & 9.12 & 49.73 \\
\hline $\begin{array}{l}T_{10}-75 \% \text { RDF + Biochar @ } 4 \text { t/ha + } \\
\text { Vermicompost @ } 2.5 \mathrm{t} / \mathrm{ha}\end{array}$ & 55.1 & 9.32 & 56.08 \\
\hline$T_{11}-100 \%$ RDF + Biochar @ 2 t/ha & 46.7 & 8.64 & 41.39 \\
\hline $\mathrm{T}_{12}-100 \%$ RDF + Biochar @ $3 \mathrm{t} / \mathrm{ha}$ & 49.8 & 8.92 & 45.15 \\
\hline$T_{13}-100 \%$ RDF + Biochar @ 4 t/ha & 51.4 & 8.96 & 48.83 \\
\hline $\begin{array}{l}\mathrm{T}_{14}-100 \% \mathrm{RDF}+\text { Biochar @ } 2 \mathrm{t} / \mathrm{ha}+ \\
\text { Vermicompost @ } 2.5 \mathrm{t} / \mathrm{ha}\end{array}$ & 48.7 & 8.84 & 45.20 \\
\hline $\begin{array}{l}\mathrm{T}_{15}-100 \% \mathrm{RDF}+\text { Biochar @ } 3 \mathrm{t} / \mathrm{ha}+ \\
\text { Vermicompost @ } 2.5 \mathrm{t} / \mathrm{ha}\end{array}$ & 54.0 & 9.24 & 55.52 \\
\hline $\begin{array}{l}\mathrm{T}_{16}-100 \% \mathrm{RDF}+\text { Biochar @ } 4 \mathrm{t} / \mathrm{ha}+ \\
\text { Vermicompost @ } 2.5 \mathrm{t} / \mathrm{ha}\end{array}$ & 56.2 & 9.40 & 66.12 \\
\hline $\mathrm{SE}(\mathrm{m}) \pm$ & 2.51 & 0.44 & 2.15 \\
\hline $\mathrm{CD}(\mathrm{p} \leq 0.05)$ & 7.26 & 1.28 & 6.27 \\
\hline
\end{tabular}


Table.4 Fresh fruit yield, fruit and haulm dry matter yield of tomato (Solanum lycopersicum L.) in acid soil under integrated nutrient management with biochar as a component

\begin{tabular}{|c|c|c|c|}
\hline Treatments & $\begin{array}{l}\text { Fresh fruit } \\
\text { yield (t/ha) }\end{array}$ & $\begin{array}{c}\text { Fruit dry } \\
\text { matter (t/ha) }\end{array}$ & $\begin{array}{c}\text { Haulm dry } \\
\text { matter (t/ha) }\end{array}$ \\
\hline $\mathbf{T}_{1}$ - Control & 8.32 & 0.86 & 0.46 \\
\hline $\mathbf{T}_{2}$ - Biochar@ 2 t/ha & 12.10 & 1.02 & 0.55 \\
\hline $\mathbf{T}_{3}$ - Biochar@3 t/ha & 14.75 & 1.13 & 0.62 \\
\hline $\mathbf{T}_{4}$ - Biochar@ 4 t/ha & 16.70 & 1.31 & 0.73 \\
\hline$T_{5}-75 \%$ RDF + Biochar @ 2 t/ha & 18.47 & 1.60 & 0.90 \\
\hline $\mathrm{T}_{6}-75 \%$ RDF + Biochar @ 3 t/ha & 21.22 & 1.78 & 1.00 \\
\hline $\mathrm{T}_{7}-75 \% \mathrm{RDF}+$ Biochar @ 4 t/ha & 23.32 & 2.06 & 1.18 \\
\hline $\begin{array}{l}\mathrm{T}_{8}-75 \% \text { RDF + Biochar @ } 2 \mathrm{t} / \mathrm{ha}+ \\
\text { Vermicompost @ } 2.5 \mathrm{t} / \mathrm{ha}\end{array}$ & 22.47 & 2.01 & 1.15 \\
\hline $\begin{array}{l}T_{9}-75 \% \text { RDF + Biochar @ } 3 \text { t/ha + } \\
\text { Vermicompost @ } 2.5 \text { t/ha }\end{array}$ & 28.35 & 3.76 & 2.23 \\
\hline $\begin{array}{l}\mathrm{T}_{10}-75 \% \text { RDF + Biochar @ } 4 \text { t/ha + } \\
\text { Vermicompost @ } 2.5 \text { t/ha }\end{array}$ & 32.62 & 4.33 & 2.58 \\
\hline$T_{11}-100 \%$ RDF + Biochar @ 2 t/ha & 22.32 & 1.86 & 1.06 \\
\hline$T_{12}-100 \%$ RDF + Biochar @ 3 t/ha & 25.22 & 2.95 & 1.74 \\
\hline$T_{13}-100 \%$ RDF + Biochar @ 4 t/ha & 27.37 & 3.34 & 1.97 \\
\hline $\begin{array}{l}\mathrm{T}_{14}-100 \% \mathrm{RDF}+\text { Biochar @ } 2 \mathrm{t} / \mathrm{ha} \\
+ \text { Vermicompost @ } 2.5 \mathrm{t} / \mathrm{ha}\end{array}$ & 24.97 & 2.26 & 1.29 \\
\hline $\begin{array}{l}\mathrm{T}_{15}-100 \% \text { RDF + Biochar @ } 3 \text { t/ha + } \\
\text { Vermicompost @ } 2.5 \text { t/ha }\end{array}$ & 32.12 & 4.29 & 2.56 \\
\hline $\begin{array}{l}T_{16}-100 \% \text { RDF + Biochar @ } 4 \text { t/ha } \\
\text { + Vermicompost @ } 2.5 \text { t/ha }\end{array}$ & 38.85 & 5.22 & 3.19 \\
\hline $\mathrm{SE}(\mathbf{m}) \pm$ & 1.27 & 0.14 & 0.08 \\
\hline $\mathrm{CD}(\mathrm{p} \leq \mathbf{0 . 0 5})$ & 3.67 & 0.40 & 0.23 \\
\hline
\end{tabular}

However, successive increase in biochar doses from lowest level of 2 t/ha to 3 and 4 t/ha slightly increased fruit and haulm dry matter over lower doses. The combined application of $75 \%$ RDF and biochar significantly increased the fruit and haulm dry matter over sole application of biochar at respective graded doses as well as over control plots. Further, significant increase in fruit and haulm dry matter was also observed with subsequent increase in RDF to $100 \%$ in combination with biochar over $75 \%$ RDF and biochar at respective graded doses. Similarly, the inclusion of vermicompost @ 2.5 t/ha with $75 \%$ RDF + biochar significantly increased the fruit and haulm dry matter over $75 \% \mathrm{RDF}$ and biochar at respective graded doses. The fruit and haulm dry matter obtained with 75\% RDF + biochar + vermicompost@2.5 t/ha was observed to be superior over $100 \% \mathrm{RDF}$ and biochar at respective graded doses. However, the addition of vermicompost @ 2.5 t/ha with $100 \% \mathrm{RDF}+$ biochar further increased the fruit and haulm dry matter over $100 \%$ RDF and biochar at respective graded doses. The trend observed for fruit and haulm dry matter yield under different treatments followed the same trend of fresh fruit yield, possibly due to the same reasons as already discussed. 
In conclusion, the combined application of biochar@4t/ha with vermicompost @ 2.5 t/ha and 100\% RDF was found to be most effective in increasing tomato yield in acid soil than sole application of biochar or biochar in combination with recommended doses of chemical fertilizers.

\section{Abbreviations}

RDF (Recommended doses of NPK fertilizers), B (Biochar), VC (Vermicompost)

\section{Acknowledgements}

The laboratory facility provided by School of Natural Resource Management, College of Post Graduate Studies in Agricultural Sciences, CAU, Umiam (Barapani) for carrying out soil and plant analysis for present study is duly acknowledged. The authors are highly thankful to the ICAR Research Complex for NEH Region, Umiam (Barapani) for proving biochar used in the study and extending other facilities.

\section{References}

Antonious, G.F. (2018). Biochar and animal manure impact on soil, crop yield and quality, In: Agricultural Waste and Residues, (ed.) Aladjadjiyan, A., Open access peer-reviewed Edited Volume, pp. 45-67. http://dx.doi.org/10.5772/ intechopen. 77008 .

Campbell, D.J. and Henshall, J.K. (2001). Bulk density. In: Soil and Environmental Analysis: Physical Methods, $2^{\text {nd }}$ ed, (eds.) K.A. Smith and C.M. Mullins, Dekker, New York, pp. 315-348.

Chan, K.Y., Van Zwieten, L., Meszaros, I., Downie, A. and Joseph, S. (2008). Using poultry litter biochars as soil amendments. Aust. J. Soil Res., 46(5): 437-444.
CRIDA (2016). Annual Report: 2016-2017, ICAR-Central Research Institute for Dryland Agriculture (CRIDA), Hyderabad. pp. 216.

DeLuca, T.H., Mackenzie, M.D. and Gundale, M.J. (2009). Biochar effects on soil nutrient transformations. In: Biochar for Environmental Management: Science and Technology, (eds.) Lehmann J. and Joseph S., Earthscan, London. pp. 251270.

Demirbas, A. (2004). Effects of temperature and particle size on bio-char yield from pyrolysis of agricultural residues. $J$. Anal. Appl. Pyrol. 72(2): 243-248.

Gomez, K. A. and Gomez, A. A. (1984). Statistical Procedures for Agricultural Research, $2^{\text {nd }}$ ed. John Wiley and Sons, New York.

Gupta, R., Sanjay-Swami and Rai, A.P. (2019). Impact of integrated application of vermicompost, farmyard manure and chemical fertilizers on okra (Abelmoschus esculentus L.) performance and soil biochemical properties. Int. J. Chem. Studies, 7(2): 1714-1718. P-ISSN: 2349-8528, EISSN: 3221-4902.

Hammond, J., Shackley, S., PrendergastMiller, M., Cook, J., Buckingham, S. and Pappa, V.A. (2013). Biochar field testing in the UK: Outcomes and implications for Use. Carbon Manag., 4: 159-170.

Jackson, M.L. (1973). Soil Chemical Analysis. Prentice Hall of India, New Delhi.

Konyak, C.P.W. and Sanjay-Swami (2018). Effect of organic and inorganic nutrient sources on yield, quality and nutrient uptake by cabbage (Brassica oleracea L. var capitata) in acid Inceptisol. Int. J. Curr. Microbiol. Appl. Sci., 7(7): 30353039.

Lehmann J., Pereira da Silva J. Jr., Steiner, C., Nehls, T., Zech, W. and Glaser, B. 
(2003). Nutrient availability and leaching in an archaeological Anthrosol and a Ferralsol of the Central Amazon basin: Fertilizer, manure and charcoal amendments. Pl. Soil, 249: 343-357.

Lehmann, J. and Joseph, S. (2009). Biochar for environmental management: An introduction. In: Biochar for Environmental Management: Science and Technology, (eds.) Lehmann J. and Joseph S., Earthscan, London. pp. 1-12.

Lehmann, J. and Rondon, M. (2006). Biochar soil management on highly weathered soils in the humid tropics. In: Biological Approaches to Sustainable Soil Systems, (eds.) Uphoff et al., Boca Raton, FL: CRC Press. pp 517-530.

Lindsay, W.L. and Norwell, W.A. (1978). Development of DTPA soil test for zinc, iron, manganese and copper. Soil Sci. Soc. Amer. J., 42: 421-428.

Lyngdoh, E.A.S. and Sanjay-Swami (2018). Phytoremediation effect on heavy metal polluted soils of Jaintia Hills in North Eastern Hill Region. Int. J. Curr. Microbiol. App. Sci., 7(11): 1734-1743. doi.org/10.20546/ijcmas.2018.711.199.

Maji, A.K., Reddy, Obi G.P. and Sarkar, D. (2012). Acid Soils of India - Their Extent and Spatial Variability. NBSS Publ. No. 145, NBSS\&LUP, Indian Council of Agricultural Research, Nagpur, pp. 1-138.

Mohideen, A.R.H. (2018). Effectiveness of biochar as a soil amendment and plant productivity. Res. J. of Agric. Forestry Sci., 6(4): 13-17.

Novak, J.M., Cantrell, K.B., Watts, D.W., Busscher, W.J. and Johnson, M.G. (2013). Designing relevant biochars as soil amendments using lignocellulosicbased and manure-based feed-stocks. $J$. Soils Sedi., 14(2): 330-343.

Oguntunde, P.G., Fosu, M., Ajayi, A.E. and van de Giesen (2004). Effects of charcoal production on maize yield, chemical properties and texture of soil. Biol. Ferti. Soils, 39: 295-299.

Renner, R. (2007). Rethinking biochar. Environ. Sci. Techn., 41(17): 59325933.

Sanjay-Swami (2019). Managing fragile hill ecosystems of North Eastern Region. In: Soil Water Conser. Today, 14 (1): 02.

Sanjay-Swami and Bazaya, B.R. (2010). Vermi-compost technology. In: Quality Seed Production of Vegetable Crops: Technological Interventions, (ed.) Sharma, J.P., Kalyani Publishers, Ludhiana, Punjab, pp. 344-356.

Sanjay-Swami and Maurya, A. (2018). Critical limits of soil available phosphorous for rapeseed (Brassica Compestris var. Toria) growing acidic soils of Meghalaya, J. Expt. Biolo. Agric. Sci., 6(4): 732-738.

Sanjay-Swami, Maurya, A. and Yadav, O.S. (2019). Towards oilseeds sufficiency in North Eastern Hill Region of India: Augmenting oilseed production in acid soils. Int. J. Chem. Studies, 7(2): 768772.

Sanjay-Swami, Yadav, O. S. and Gurjar, G.N. (2018). Use of biochar for increasing carbon sequestration in soil. In: Souvenir, $27^{\text {th }}$ National Conference of SCSI on "Sustainable Management of Soil and Water Resources for Doubling Farmers' Income" (eds.) Bipul Deka et al., October 25-27, 2018, Assam Chapter of SCSI, AAU, Jorhat, Assam, pp. 75-77.

Subbiah, B.V. and Asija, G.L. (1956). A rapid procedure for the determination of available nitrogen in soil. Curr. Sci., 25: 259-260.

Yadav, O.S. and Sanjay-Swami (2018). Utilizing bio-char potential for acid soil management. In: Soil and Water Conser. Today, 13 (4): 05-06.

Yamato, M., Okimori, Y., Wibowo, I.F., Anshori, S., and Ogawa, M. (2006). 
Effects of the application of charred bark of Acacia mangium on the yield of maize, cowpea and peanut, and soil chemical properties in South Sumatra, Indonesia. Soil Sci. Pl. Nutr., 52(4): 489-495.

Zhang, A., Liu, Y., Pan, G., Hussain, Q., Li,
L., Zheng, J., and Zhang, X. (2012). Effect of biochar amendment on maize yield and greenhouse gas emissions from a soil organic carbon poor calcareous loamy soil from Central China Plain. Pl. Soil, 351 (1-2): 263275.

\section{How to cite this article:}

Oguboyana Srikanth Yadav and Sanjay Swami. 2019. Performance of Tomato (Solanum lycopersicum L.) in Acid Soil under Integrated Nutrient Management with Biochar as a Component. Int.J.Curr.Microbiol.App.Sci. 8(05): 793-803.

doi: https://doi.org/10.20546/ijcmas.2019.805.094 